\section{Sex and gender identity differences in psychological job outcomes among salespeople}

\author{
Ceyda Tanrikulu \\ Adana Science and Technology University, Department of \\ International Trade and Finance, Adana, Turkey
}

\begin{abstract}
Purpose - The purpose of this study was to determine whether there was any difference among sex and gender identity groups for salespeople in terms of psychological job outcomes, namely job stress, organizational commitment, intention to leave, and job satisfaction.
\end{abstract}

Design/methodology/approach - Data was collected from salespeople using a survey. The questionnaire used was administered to a convenience sample of pharmaceutical salespeople from south-central region of Turkey, through a self-administered questionnaire.

Findings - The findings suggested that there were differences between sex groups in psychological job outcomes except job stress, while there were differences between gender identity groups in all of them. There already exist sex differences and also gender identity differences regarding the job outcomes in sales force. Androgynous individuals have the most appropriate gender identity for sales profession, considering that they had a high level of job satisfaction and organizational commitment and a low level of job stress and intention to leave.

Originality/value - The major contribution of this study to the literature and administrative implications is the enrichment of information concerning gender-based similarities and/or differences among salespeople in terms of job outcomes with a new and different approach.

Keywords - Sex; gender identity; psychological job outcomes; salespeople; sales management.
Received on

04/30/2016

Approved on

02/07/2017

\section{Responsible editor:}

Prof. Dr. João Maurício Gama

Boaventura

\section{Evaluation process:}

Double Blind Review

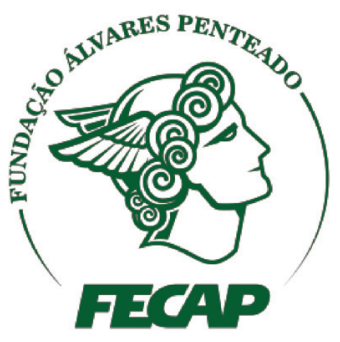

Review of Business

Management

DOI: $10.7819 /$ rbgn.v0i0.2302 


\section{Introduction}

Gender in sales management is a significant and newsworthy subject matter to be analyzed in terms of administrative implications and academic studies, by virtue of (biological) sex based diversity resulting from the participation of women in sales force and the ever increasing number of these women (Macintosh \& Krush, 2014; McQuiston \& Morris, 2009; Rutherford, Marshall, \& Park, 2014), changes in characteristics of gender identity (psychological gender) required by the sales profession, and changes in gender identity. Furthermore, gender-based analysis on sales force in terms of psychological job outcomes (job stress, intention to leave, organizational commitment and job satisfaction) offers a different and effective insight into the attitudes of salespeople towards their job by classifying individual differences. It also highlights administrative implications in a broad range, from selection of salespeople to their training.

In light of the current literature, matters mentioned below require a detailed analysis on sales force in terms of both sex and gender identity to understand changes of sales force and manage it in the course of time.

- Diversity in gender: Even though it is predicted that the difference between men and women in sales profession has decreased with the passing of time and is expected to go on decreasing (Monciref, Babakus, Cravens, \& Johnston, 2000), current research shows that there are still some differences (Macintosh \& Krush, 2014; Rutherford et al., 2014). Furthermore, some studies on gender identity point out that masculine characteristics of women have increased due to cultural, social, and economic reasons (Özkan \& Lajunen, 2005; Twenge, 1997) and no change has occurred in the femininity level of men (Twenge, 1997). Thus, it is suggested that gender identities has undergone a change (Demirtaş-Madran, 2012; Özkan \& Lajunen, 2005; Twenge, 1997).

- Inconsistent findings in sex: Although gender is an important matter of research in sales literature, it is also emphasized that there are problems with the difficulty and inconsistency in reaching a binding conclusion regarding the presence of any difference among salespeople in terms of sex (Beetles \& Haris, 2005; Macintosh \& Krush, 2014; Monciref et al., 2000).

- Limited number of studies in gender identity: It is also clear that studies on gender are mostly based on biological aspects, and there is a limited number of studies on psychological features. This limited number of studies mainly focuses on the characteristics of gender identities that fit into the sales profession (Comer \& Drollingerr, 1996; Comer \& Jolson, 1991; Goolsby, Lagace, \& Boorom, 1992; Jolson \& Comer, 1997; Lagace \& Twible, 1990; Spiro \& Weitz, 1990; Teer, Tobacyk, \& Dawson, 1992). Thus, there is a research gap about gender identity in terms of psychological job outcomes which should be fulfilled.

- Impact of gender identity: It is indicated that sex has no impact especially on job satisfaction and job stress. However, there may be a strong relationship between masculinity and femininity characteristics as gender identity groups and them (Eichinger, 2000; Eichinger, Heifetz, \& Ingraham, 1991).

- Culture: In general literature, there are mixed results on gender identity in terms of psychological job outcomes (Eichinger, 2000; Eichinger et al., 1991; Ushasree, Seshu Reddy, \& Vinolya, 1995). It is thought that these mixed results stem from cultural differences (Eichinger, 2000). To this extent, a study on psychological job outcomes of salespeople in Turkey in the context of gender identity groups 
will arouse interest for researchers and practitioners, as it will fill the gaps in literature and support administrative implications. It will also provide findings about salespeople with cultural properties different from the countries in previous studies. It is suggested that it is essential to examine the gender identity in Turkey, as an emerging market, because of its culture mixing Western and Islamic culture and reasons such as increase in urbanization, industrialization, international and regional migration and education opportunities and protection of working women's rights (Özkan \& Lajunen, 2005). Furthermore, an analysis on women in sales force under the circumstances in Turkey will be useful for both the literature and administrative practitioners, as women have recently participated in the sales profession and the number of these women increases rapidly.

Based on the aforementioned necessities and gaps in the literature, the purpose of the this study was to determine whether there is any difference among sex and gender identity groups for salespeople in terms of psychological job outcomes. For this purpose, research questions were gathered under two main titles. These were:

- Are there sex differences in psychological job outcomes for salespeople? If any differences exist, which group has a higher level of psychological job outcomes for each type?

- Are there gender identity differences in psychological job outcomes for salespeople? If any differences exist, which gender identity group has a higher level of psychological job outcomes for each type? This study analyzed the psychological job outcomes in terms gender identity as distinct from previous studies analyzing gender in sales force. In comparison to other workers, salespeople maintaining consistent connection with customers provide opportunities to learn customer needs, create targeted product proposals and sales pitches (Chai, Zhao, \& Babin, 2012), and subsequently they have key roles in creating long-term customer relationship (Robinson, Marshall, Moncrief, \& Lask, 2002; Weitz \& Bradford, 1999). Salespeople are the strong representatives of the organizations thus, the individual differences between the salespeople should be taken into account in order to manage the salespeople effectively. Furthermore, this study was conducted in an emerging market, unlike other studies that have been conducted in developed countries. Therefore, the main expected contribution of this study to the literature and administrative implications is the enrichment of information concerning gender-based similarities and/or differences among salespeople in terms of job outcomes with a new and different approach.

\section{Background and hypotheses}

\section{I Sex and gender identity}

Sex is biologically divided into two groups: female and male while gender identity is psychologically grouped as masculine, feminine, androgen and undifferentiated (Bem, Martyna $\&$ Watson, 1976). Gender identity is related to part of individuals' self-concept effected by cultural description about the regarding favorable properties of women and men (Schruijer, 2006).

Bem's gender identity theory and related measures are accepted as the most popular approach to date, and it is seen that her gender identity groups and measures are used in upto-date research studies (Bolat \& Odac1, 2016; Koca, Aşçı, \& Kirazcı, 2005; Matud, Bethencourt, \& Ibáñez, 2014; Özkan \& Lajunen, 2005; Ramkissoon \& Nunkoo, 2012; Winterich, Mittal, \& Ross, 2009; Yoon \& Kim, 2014). Bem's approach is also widely utilized by various social scientists such as psychologists, sociologists to understand gender identity and its relations to behaviors. Bem's sex role inventory (BSRI) offer a direct measure of gender identity in which 
participants clearly rate themselves on different personal characteristics, resulting in scores on rating scales (Wood \& Eagly, 2015).

In addition to these, since gender identity depends on the desirable feature attributed to men and women by a given culture (Özkan $\&$ Lajunen, 2005; Schruijer, 2006; Wood \& Eagly, 2012, 2015), the approach suitable for Turkish culture should be considered. It is seen in literature that Bem's approach is widely used in studies regarding the gender identity in Turkish culture (Arslan, 2014; Bolat \& Odac1, 2016; Koca et al., 2005; Özkan \& Lajunen, 2005; Tanrikulu, 2014; Tanrıkulu \& Efeoğlu, 2015; Yağc1 \& İlarslan, 2010). Thus, Bem’s approach is preferred in this study.

Based on Bem's approach, gender identity represents that individuals confirming gender stereotypic traits as self-descriptive are assumed to integrate themselves into their self-concepts and guide their behavior associated with this self-knowledge (Wodd \& Eagly, 2015). In a society, individuals adopting characteristics attributed to men are described as masculine and those upholding characteristics attributed to women are described as feminine individuals (Özkan \& Lajunen, 2005). A man may have feminine characteristics, while women may have the characteristics of masculinity. Androgen individuals have high level of both masculine and feminine characteristics and undifferentiated individuals have low level of both masculine and feminine characteristics (Bem et al., 1976).

Bem's approach suggests that masculine characteristics are responsible for their family, dominant, non-demonstrative, masculine, forceful, sociable, coming out against injustice, ambitious, idealist, defending their own needs, self-confident, prim and proper, acting as a leader, sensible, authoritarian, willing to take risks, aggressive and willing to keep promises. Feminine characteristics are: affectionate, cheerful, childlike, compassionate, not using harsh language, eager to soothe hurt feelings, feminine, flatterable, gentle, gullible, loves children, loyal, sensitive to the needs of others, shy, soft-spoken, sympathetic, tender, understanding, warm, and yielding (Dökmen, 1999). Androgynous individuals have high level of masculine and feminine characteristics and display both instrumentality, namely focus on the performance of a work or solution of a problem, and expressiveness, namely well-being of others and group cohesiveness (Bem et al., 1976). Androgynous individuals may also demonstrate flexibility in mutual relationships among individuals. This flexibility develops on the basis of situational convenience of the behavior (Spiro \& Weitz, 1990). Androgens are also known as having higher self-expectation and better performance in competitive environment (Gianakos, 2000), more self-efficacy in career decision making (Bolat \& Odac1, 2016; Gianakos, 2000), having a lower anxiety level (Demirtaş-Madran, 2012), more learning oriented (McFarland \& Kidwell, 2006: 147), and to be good listeners (Comer \& Drollinger, 1999).

\subsection{Sex and gender identity in psychological job outcomes}

\subsection{Job stress}

Stress is the physical and emotional reaction to the potential threats of the environment (Akgemci, 2001). In the sales management literature, job stress is accepted as a psychological process and assumed to occur when the salesperson cannot reach or exceed his job-related expectations (Sager \& Wilson, 1995).

Salespeople are thought to have a great tendency to experience job stress. The main reason behind this tendency is the specific nature of the sales profession. Scope of the boundaries of salespeople' roles and attention grabbing nature of their performances cause job stress. Salespeople are required to meet conflicting demands of their managers and customers and maintain regular communication with them in order to achieve job targets. This leads to a stressful work environment most of the time (Sager \& Wilson, 1995). Reasons like personality 
traits, role conflicts, role ambiguity, inexperience, workload, management style, and work-family conflict are other determining factors on job stress of salespeople (Yapraklı \& Yılmaz, 2007).

Gender is assumed as a significant factor determining the stress in workplace (Bickford, 2005; Gaur \& Jain, 2013; Rivera-Torres, AraquePadilla, \& Montero-Simó, 2013) and it is suggested that women feel negative impacts of stress more than men (Bickford, 2005; Rivera-Torres et al., 2013). However, in their leading study on gender differences in sales force, Monciref et al. (2000) show that there is no difference of job stress among saleswomen and salesmen, and a recent research confirms this result (Mulki, Jaramillo, Goad, \& Pesquera, 2015). Research conducted on sales literature reveals no study on psychological gender, however, it is seen in the general literature that there is a difference among psychological gender groups. A study on bank employees suggests that there is no difference of job stress perceptions of women and men, however, there is a difference associated with gender identity. In this regard, masculine individuals have a lower level of job stress when compared to feminine individuals. This is grounded on the psychological origin of job stress and higher importance of the relationship of psychological gender with job stress than its relationship with biological sex (Shen, 2014; Wu \& Shih, 2010). Androgynous persons have more adaption to workplace stress than others, and in case they have workplace stress, they display help seeking, positive thinking, and direct action more than other gender identities and use strategies to adapt to specific situation demands (Gianakos, 2000). According to the behavioral flexibility theory, androgynous individuals having both masculine and feminine characteristics are able to give more appropriate responses to various situations when compared to other individuals. In other words, thanks to the "behavioral flexibility", they experience a lower level of stress and thus have better psychological health (Eichinger, 2000). Recent studies indicate that they have a lower anxiety level (Cheng,
2005; Demirtaş-Madran, 2012), lower levels of perceived stress (Jones, Mendenhall, \& Myers, 2016), higher level of mental health, well-being and happiness (Demirtaş-Madran, 2016) and also are less prone to depression (Demirtaş-Madran, 2012). Considering the given information, it was expected in this study that there would be an equal level of job stress among biological sex groups and a different level of job stress among gender identity groups. Thus;

H1: There is not a difference in sex groups regarding the means of job stress.

H2: There is a difference in gender identity groups regarding the means of job stress.

\subsubsection{Intention to leave}

Intention to leave is thought to be a good estimator in the prediction of employees' turnover (Choi, 2006) while gender differences are accepted highly important factor to find out the development of turnover decision (Wiesberg \& Kirschenbaum, 1993). Recent studies have offered inconsistent results on gender differences/ similarities regarding the intention to leave (Selvarajan, Slattery, \& Stringer, 2015; Shukla \& Srivastava, 2016). Women may have a high level of intention to leave due to reasons like pregnancy, maternity and discrimination at work (Nelson \& Quick, 1985). Ladik, Marshall, Lassk, \& Moncrief (2002) determined that salesmen with high performance have a higher intention to leave when compared to saleswomen with high performance. It is found out in the pioneering studies in the sales literature that saleswomen have a higher intention to leave when compared to that of salesmen (Busch \& Bush,1978; Monciref et al., 2000; Schul \& Wren,1992). No study analyzing intention to leave in terms of psychological gender was found in the literature research.

Women were expected to have a higher level of intention to leave in this study considering dominant findings in the literature. It was anticipated that feminine characteristics like 
being loyal and sympathetic would scale down the intention to leave and masculine characteristics like ambition, willingness to take risk, and courage would scale up this intention. Therefore, hypotheses were:

H3: There is a difference in sex groups regarding the means of intention to leave.

H4: There is a difference in gender identity groups regarding the means of intention to leave.

\subsubsection{Organizational commitment}

Organizational commitment means biased and emotional commitment of employees to the goals and values of the organization they work for. It is suggested that organizational commitment consists of internalization addressing to the employee's perception of targets and goals of the organization as their own targets and goals, adoption addressing to the employee's adoption of their roles and services in the organization, and loyalty addressing to the employee's loyalty to the organization (Buchanan, 1974). All organizations and their departments desire their employees to be committed to them. This is because employees with a high level of organizational commitment devote more capability, energy and time to their organization (Hunt, Chonko, \& Wood, 1985). Salespeople with high organizational commitment may produce results in favor of the organization with regard to matters like job satisfaction, intention to leave, leave of job, and customerbased sales (Jaramillo, Mulki, \& Marshall, 2005). In the sales management literature, it is suggested that there is no difference between saleswomen and salesmen in terms of organizational commitment (Macintosh \& Krush, 2014; Monciref et al., 2000; Paul \& Garg, 2014; Siguaw \& Honeycutt, 1995; Schul \& Wren, 1992) without Tyagi and Wotruba (1998). It is also stated that the level of organizational commitment may vary depending on the industry and number of saleswomen within the sales force (Monciref et al., 2000). No study analyzing organizational commitment in terms of gender identity was found in the literature reviews.

On the basis of findings in the literature, it was expected in this study that there would be no difference of organizational commitment among biological sex groups. It was also expected that feminine characteristics like being loyal, friendly, and sympathetic would bring organizational commitment, while masculine characteristics like being dominant, risk-taking, ambitious, and courageous would reduce organizational commitment. Thus, hypotheses were:

H5: There is not a difference in sex groups regarding the means of organizational commitment.

H6: There is a difference in gender identity groups regarding the means of organizational commitment.

\subsubsection{Job satisfaction}

Job satisfaction is described as a set of positive and negative feelings and emotions of employees for their jobs (Newstrom \& Davis, 1993). In the sales management literature, job satisfaction is accepted as a result of the satisfactions felt for the job itself, wage, promotion, workmates, managers, company policies and customers, which are qualified as the dimensions of job satisfaction (Boles, Wood, \& Johnson,2003; Rutherford, Boles, Hamwi, Madupalli, \& Rutherford, 2009). Satisfied salespeople may generate favorable results for their organizations. For instance, these salespeople have a higher tendency to keep their job and ability to work harder when compared to other salespeople (Boles et al., 2003).

The sales management literature gives mixed results concerning whether being a woman or a man will make any difference in their job satisfaction. There are results suggesting both that saleswomen have a lower level of job satisfaction (Kennedy \& Lawton, 1992; Swan, Futrell, 
\& Todd, 1978) and that they have a higher level of job satisfaction (Gable \& Reed, 1987; Tyagi \& Wotruba, 1998). On the other hand, results showing that there is no difference of job satisfaction level among salespeople in terms of sex are also found (Busch \& Bush, 1978; Çabuk \& Keleş, 2011; Franke \& Park, 2006; Macintosh \& Krush, 2014; Monciref et al., 2000; Schul \& Wren, 1992; Siguaw \& Honeycutt, 1995). In such studies presenting no difference, this result is grounded on the eventually decreasing tokenism and gender discrimination for saleswomen, personal and social practices specific to women (Monciref et al., 2000), women's embracing the sales profession and developments in favor of women. Saleswomen's high level of job satisfaction is based on considering sales profession as a career opportunity (Gable \& Reed, 1987), and it is also suggested that this high level of job satisfaction stems from their lower expectations from the job when compared to men (Clark, 1997). When reviewed in terms of job satisfaction, there are mixed results in the literature. A relevant study suggests that support of managers is important for the job satisfaction of saleswomen and there is no difference between women and men with regard to the support of workmates (Dubinsky, Jolson, Michaeles, Kotabe, \& Lim, 1993). Another study reveals that there is no difference of satisfaction level between women and men in terms of wage, customers, job itself, managers, promotion and workmates (Busch \& Bush, 1978).

It is seen in the general literature that there are differences of job satisfaction among gender identity groups (Eichinger, 2000; Eichinger, Heifetz \& Ingraham, 1991; Jagacinski, 1987; Krausz \& Kedem, Tal, \& Amir, 1992; LipinskaGrobelny \& Wasilak, 2010). They show that androgynous individuals have a higher level of job satisfaction. Behavioral flexibility of androgynous individuals is accepted to be the reason behind their high level of job satisfaction (Eichinger, 2000). However, no study analyzing the job satisfaction in terms of gender identity groups was found in the sales literature reviews.
In accordance with the general tendency in the literature, it was expected in this study that the level of job satisfaction of salespeople would not change according to the biological sex, but vary according to the gender identity groups. In this regard:

H7: There is not a difference in sex groups regarding the means of job satisfaction.

H8: There is a difference in gender identity groups regarding the means of job satisfaction.

\section{Method}

\section{I Sample}

The sample covered pharmaceutical salespeople from south-central region of Turkey. Based on a recent study conducted in this region, it was understood that there were 22 pharmaceutical companies and approximately 700 salespeople were employed in them (Kara, Andaleeb, Turan, \& Cabuk, 2013). Sekaran (2003) asserts that the appropriate sample size is 248 when the population includes 700 individuals. Considering this value and the possibility of inaccurate and uncompleted questionnaires, 310 questionnaires were decided to be applied, 307 of which were useful for the analysis. Using convenience sampling, the data was obtained from pharmaceutical salespeople via self-administered questionnaire method. The variety of demographical features of the participants was taken into account during the distribution of the questionnaires. The questionnaires were distributed and collected by 4 pollsters in three months in 2014, with no missing values. Questionnaires lasted $15 \mathrm{~min}$ on average.

The demographic characteristics of respondents were as follows: $37.1 \%$ of the respondents were female and $62.9 \%$ were male. Average age was between 25-38 years, 65.5\% of respondents were married, and $22.4 \%$ of the participants had an income between 2001 and 3000 TL. Also, most of them had a bachelor degree $(91.8 \%)$. 


\subsection{Questionnaire and scale}

The questionnaire form included items to measure job stress, organizational commitment, intention to leave, and job satisfaction as psychological job outcomes and psychological gender (gender identity). The respondents were required to inform their agreement degree in 79 items and answer 5 demographical questions. All the variables were measured using seven-point Likert scales formed as, ' 1 - certainly disagree', ' 4 - neither agree nor disagree', and '7 - certainly agree' for job stress, organizational commitment, intention to leave and job satisfaction. In the scales of gender identity, ' 7 means never suitable; 4 means neither suitable nor unsuitable; 1 means always suitable'. Well-established scales were purposive to facilitate appraisement of the research variables. Thus, all the measures were drawn from previous research in the literature that has widely used and proven their validity and reliability. Scale for job stress was taken after House and Rizzo (1972); organizational commitment was assessed using the short form scales from Mowday, Steers, \& Porter, 1979; scale for intention to leave was taken after Seashore, Lawler, Mirvis and Cammann (1982) and job satisfaction was measured by using the scale of Minnesota short form (Weiss, Davis, \& England, 1967). As to gender identity, considering that it is reflected by culture (Schruijer, 2006; Wood \& Eagly, 2015), the Turkish culture version of BSRI developed by Dökmen is used (Dökmen, 1999). Its reliability and validity analyses were also performed by Dökmen (Dökmen 1991, 1999). This scale includes 20 masculine and 20 feminine personality traits.

As a pre-test, preliminary versions of the questionnaire were practiced with 40 salespeople to assure that the participants understood the questions clearly and that no semantic and measurement problems existed. After making the necessary revisions, the questionnaire was conducted to participants.

\subsection{Measure validation and descriptive statistics}

Cronbach $\alpha$ coefficients were calculated to determine the reliability of scales used in the study. The internal consistency for all of the scales were reasonable, seeing that the reliability of each scale exceeded the criterion of 0.70 typically judged as acceptable (Hair, Celsi, Money, Samouel, \& Page, 2011), as presented in Table 1.

Table 1

Descriptive statistics of the research variables

\begin{tabular}{lccccccc}
\hline Variables & $\alpha$ & Mean & Std. Dev. & JS & OC & ITL & JSAT \\
\hline JS & 0.824 & 4.454 & 1.341 & 1 & $-0.378^{* *}$ & $0.591^{* *}$ & $-0.375^{* *}$ \\
OC & 0.895 & 4.523 & 1.221 & $-0.378^{* *}$ & 1 & $-0.529^{* *}$ & $0.521^{* *}$ \\
ITL & 0.919 & 3.281 & 1.811 & $0.591^{* *}$ & $-0.529^{* *}$ & 1 & $-0.433^{* *}$ \\
JSAT & 0.913 & 4.989 & 0.894 & $-0.375^{* *}$ & $0.521^{* *}$ & $-0.433^{* *}$ & 1 \\
\hline
\end{tabular}

Note. ${ }^{* *}$ Correlation is significant at the 0.01 level (2-tailed)

1 - certainly disagree; 4 - neither agree nor disagree; 7 - certainly agree.

JS: job stress; OC: organizational commitment; ITL: intention to leave; JSAT: job satisfaction

Various non-statistical methods can be helpful to measure validity comparing to reliability (Gegez, 2010). To establish validity, all scales used in the study were adopted from previous studies (mentioned above) where the reliability and validity of the measures are confirmed. Furthermore all the measures which are used as unidimensional were drawn from previous research from both Turkish and global literatures that have widely used and proven 
their validity and reliability many times (Bilgiç, 2010; Schul \& Wren, 1992; Sims \& Sun, 2012; Swimberghe, Jones, \& Darrat, 2014; Turunç \& Erkuş, 2010; Wren, Berkowitz, \& Grant, 2014). Three academicians criticized the scales to support content validity. A pre-test was performed to increase the understanding of the statement and prevent semantic and measurement problems. As seen in Table 1, the correlation coefficient of the variables provided evidence supporting the nomological validity, which means scales used in this study, known to be correlated theoretically, have significant correlation between them. Consistent with the literature, the positive correlation was found between OC and JSAT (Boles et al., 2003; Brashear, Lepkowska-White, \& Chelariu, 2003; Choi \& Kim, 2016; Fu \& Deshpande, 2014; Jaramillo, Grisaffe, Chonko, \& Roberts, 2009; Jaramillo, Mulki, \& Solomon, 2006; Macintosh \& Kursh, 2014), while a significant negative correlation was found between JS and both OC (Choi \& Kim, 2016; Jaramillo et al., 2009; Lambert, Minor, Wells, \& Hogan, 2016) and JSAT (Jaramillo et al. 2009; Johson \& Sohli, 2014; Lambert et al., 2016; Yapraklı \& Yilmaz, 2007). The negative correlations were also observed to be coherent with the previous research between ITL and both OC (Babakus, Cravens, Johnston, \& Moncrief, 1996; Brashear et al., 2003; Jaramillo et al., 2009; Jaramillo et al., 2006; Naumann, Widmier, \& Jackson, 2000) and JSAT (Babakus et al., 1996; Boles, Madupalli, Rutherford, \& Wood, 2007; Brashear et al., 2003; Jaramillo et al., 2009; Jaramillo et al., 2006; Naumann et al., 2000).

The means of all variables ranged from 3.281 to 4.989 as given in Table 1. It was observed that the respondents had medium level job stress and organizational commitment and had relatively higher job satisfaction. It could also be claimed that they had lower level of intention to leave. Also, the correlation coefficients ranged from -0.375 to 0.591 which denoted medium and weak level correlations between the variables (Table 1).

\subsection{Data analysis}

SPSS 16 (SPSS Inc., Chicago, IL, USA) software was used in all statistical analyses. The analysis of independent sample $t$-test was carried out to determine whether there is a difference in sex and gender groups regarding the job stress, organizational commitment, intention to leave, and job satisfaction or not, as in many previous research about the sex and gender differences (Bolat \& Odacı, 2016; Gianakos, 2000; Özkan \& Lajunen, 2005; Schruijer, 2006; Tanrıkulu, 2014). Based on the central limit theorem, it was accepted that the assumption of normality was satisfied in this study ${ }^{1}$.

\section{Results}

The results of the $t$-test analyses carried out to determine the sex difference in psychological job outcomes were presented in Table 2. It could be deduced from $t$-test that there were significant statistical differences between sex groups in organizational commitment $(\mathrm{t}=4.0947, p<0.05)$, intention to leave $(\mathrm{t}=-3.497, p<0.05)$ and job satisfaction $(\mathrm{t}=2.088, p<0.05)$ while that was false for job stress $(p>0.05)$. Thus, $\mathrm{H} 1$ and $\mathrm{H} 3$ were supported but $\mathrm{H} 5$ and $\mathrm{H} 7$ were not. The results indicated that both women and men had equal means regarding job stress although women had higher organizational commitment and job satisfaction and had lower intention to leave.

Gender identities of participants were identified by using Dökmen's approach (1999) before performing the t-test for hypothesis about the gender identity group differences. Among participants, those with a median of 5.55 and above, in respect of answers given to femininity statements in the gender identity scale, were determined as feminine and those with a median of 5.20 and above in respect of answers given to masculinity statements were determined as masculine with respect to Dökmen (1999). Also, participants remaining below medians in both types of points were classified as indifferent and those above these medians 
were classified as androgynous. Accordingly, $8.47 \%$ (26 participants) of participants were classified as feminine, $40.72 \%$ (125 participants) as masculine, $43.00 \%$ (132 participants) as androgynous and $7.81 \%$ (24 participants) as indifferent. In this study, only masculine and androgynous groups were analyzed since, for a solid statistical analysis, each group should have at least 30 respondents (Altunışık, Coskun, Yildirim, \& Bayraktaroglu, 2002; Sekaran, 2003).

The results of the $t$-test for the gender identity group differences were shown in Table 2. It was understood from the results of the $t$-test that there existed statistically significant differences between gender identity groups in job stress $(\mathrm{t}=3.013, p<0.05)$, intention to leave $(\mathrm{t}=4.468, p<0.05)$, organizational commitment $(\mathrm{t}=-3.994, p<0.05)$, and job satisfaction $(t=5.649$, $p<0.05)$ which implied that masculine and androgynous respondents had different means regarding the psychological job outcomes. Thus, H2, H4, H6, and H8 were accepted. The means of each group were taken into account in order to determine which group had higher psychological job outcomes. The results demonstrated that the means of masculine respondents were higher in both job stress (4.680) and intention to leave (3.770), whereas androgynous respondents were higher in both organizational commitment (4.780) and job satisfaction (5.334). The androgynous respondents had more organizational commitment and job satisfaction while they had lower job stress and intention to leave.

Table 2

\section{Results of $t$-test}

\begin{tabular}{|c|c|c|c|c|c|c|c|}
\hline Variables & $\mathbf{N}$ & Mean & Std. Dev. & Levene's sig. & $\mathbf{t}$ & Sig. & results \\
\hline \multicolumn{8}{|l|}{ JS } \\
\hline Women & 114 & 4.271 & 1.313 & 0.717 & -1.837 & 0.067 & Women=men \\
\hline Men & 193 & 4.561 & 1.349 & & & & \\
\hline \multicolumn{8}{|l|}{ OC } \\
\hline Women & 114 & 4.917 & 0.886 & 0.000 & 4.0947 & 0.000 & Women $>$ men \\
\hline Men & 193 & 4.290 & 1.330 & & & & \\
\hline \multicolumn{8}{|l|}{ ITL } \\
\hline Women & 114 & 2.839 & 1.580 & 0.008 & -3.497 & 0.001 & Women $<$ men \\
\hline Men & 193 & 3.542 & 1.890 & & & & \\
\hline \multicolumn{8}{|l|}{ JSAT } \\
\hline Women & 114 & 5.127 & 0.874 & 0.764 & 2.088 & 0.038 & Women $>$ men \\
\hline Men & 193 & 4.907 & 0.898 & & & & \\
\hline \multicolumn{8}{|l|}{ JS } \\
\hline mas & 125 & 4.680 & 1.277 & 0.223 & 3.013 & 0.003 & Mas $>$ and \\
\hline and & 132 & 4.173 & 1.410 & & & & \\
\hline \multicolumn{8}{|l|}{ OC } \\
\hline mas & 125 & 4.158 & 1.280 & 0.180 & -3.994 & 0.000 & Mas $<$ and \\
\hline and & 132 & 4.780 & 1.215 & & & & \\
\hline \multicolumn{8}{|l|}{ ITL } \\
\hline mas & 125 & 3.770 & 1.753 & 0.263 & 4.468 & 0.000 & Mas $>$ and \\
\hline and & 132 & 2.770 & 1.831 & & & & \\
\hline \multicolumn{8}{|l|}{ JSAT } \\
\hline mas & 125 & 4.724 & 0.785 & 0.001 & -5.649 & 0.000 & Mas $<$ and \\
\hline and & 132 & 5.334 & 0.942 & & & & \\
\hline
\end{tabular}

Note. JS: job stress; OC: organizational commitment; ITL: intention to leave; JSAT: job satisfaction; mas: masculine; and: androgynous 


\section{Discussion and conclusion}

This study examined whether there was any difference among sex and gender identity groups according to psychological job outcomes. To this extent, job stress, organizational commitment, intention to leave, and job satisfaction were accepted as psychological job outcomes.

According to the basic findings of the study, female and male participants had an equal level of job stress. This finding was compatible with the previous findings suggesting that there is no difference of job stress between saleswomen and salesmen (Jaramillo et al., 2009; Monciref et al., 2000; Yapraklı \& Yılmaz, 2007). Thus, it may be argued that sex has a decreasing importance in the sensation of stress arising from the sales profession. On the other hand, findings of this study comparing masculine and androgynous individuals showed that androgynous ones had a lower level of job stress. Previous findings indicating that androgynous individuals have a lower level of anxiety and tendency to depression (Demirtaş-Madran, 2012; Dökmen, 2003), lower level of perceived stress (Jones et al., 2016), less affected by societal pressure and traditional impositions (Bolat \& Odac1, 2016), dreams about positive things and feel adequacy (Dökmen, 2003) support this finding of the study. In addition, strategies of coping with stress (Cheng, 2005; Gianakos, 2000) and behavioral flexibility (Eichinger, 2000) specific to androgynous individuals were thought to have an influence on androgynous participant's lower level of job stress and their ability to manage and cope with the stress caused by the sales profession. Androgynous salespeople have the ability to respond appropriately, be relaxed, and thus adapt to unexpected situations in various sales circumstances (Jolson \& Comer, 1997) that may be why they have a lower level of job stress in the sales environment, which requires multiple roles for salespeople. With a general view to job stress in terms of sex and gender identity, findings of this study verify the findings of previous studies arguing that gender identity is important rather than (biological) sex (Shen, 2014; Wu \& Shih, 2010). In light of these findings, sales managers should take gender identity (psychological gender) into account in order to reduce job stress.

It is determined that participants generally did not have an intention to leave, however male participants had a higher intention to leave when compared to women participants. This finding supported the finding of a previous study (Ladik et al., 2002), while it did not comply with some others (Busch \& Bush, 1978; Monciref et al., 2000; Schul \& Wren,1992). On the other hand, it was thought that the reason behind participants' low level of intention to leave could be their adoption of the sales profession and the organization they work for. Moreover, female participants' low intention to leave shows that women's loyalty and recessiveness to take risks, work life and sales community change in favor of women and women get stronger in the work life. Another finding of this subject showed that masculine participants had a higher level of intention to leave. The fact that men and masculine persons are ambitious and willing to take risks may steer them into better jobs. Also, androgynous individual's flexibility and having higher career decision-making self-efficacy (Bolat \& Odac1, 2016) may be the explanations for their low level of intention to leave.

In contradistinction to previous studies (Monciref et al., 2000; Schul \& Wren, 1992; Siguaw \& Honeycutt, 1995), it was determined in this study that female participants had a higher level of organizational commitment, which supported Tygai and Wotruba (1998). This surprising finding was thought to be caused by socio-economic and cultural differences among countries where the study was conducted. Another relevant finding was that androgynous participants had higher organizational commitment. It was suggested that behavioral flexibility characteristics of androgynous individuals provide an advantage in this regard. 'These individuals' capability to display situational behaviors ensures that they perceive 
goals and purposes of the organization like their own goals and purposes and adopt the service they provide (Buchanan, 1974), which serve as the building blocks of organizational commitment, and increase their organizational commitment. Also, the negative correlation between $\mathrm{OC}$ and ITL observed in this study and literature confirms the high level of OC for androgynous individuals with low level of intention to leave. Furthermore, the properties of androgynous individuals being less affected by societal pressure and traditional impositions (Bolat \& Odac1, 2016) and feeling adequacy (Dökmen, 2003) may also be the reason for high level of OC.

A key finding of the study was that job satisfaction showed difference among sex groups and women had a higher level of job satisfaction. While this finding promoted certain studies with mixed results in the sales literature (Gable \& Reed, 1987), it was contrary to the studies suggesting that there is no difference (Busch \& Bush, 1978; Çabuk \& Keleş, 2011; Franke \& Park, 2006; Monciref et al., 2000; Schul \& Wren, 1992; Siguaw \& Honeycutt, 1995). This may be grounded on the fact that women see the sales profession as a career opportunity (Gable $\&$ Reed, 1987) and have a lower expectation from the job (Clark, 1997) or that women adopt the sales profession and have the ability to cope with the difficulties of this profession. It also supported the suggestions of other finding of this study that women and men had no difference of job stress in terms of coping with difficulties and they experienced a medium level of job stress.

According to another important finding of the study, there was a difference in job satisfaction levels of gender identity groups, and androgynous individuals had a higher level of job satisfaction when compared to masculine individuals. This finding provided further support to contention about the behavioral flexibility (Bem \& Lewis, 1975 ) and findings of previous studies (Eichinger, 2000; Eichinger et al., 1991; Jagacinski, 1987; Krausz et al., 1992; Lipinska-Grobelny \& Wasilak, 2010). Many studies in the literature suggest that, as a requirement of the current sales conditions, salespeople should display both masculine and feminine characteristics, namely androgynous characteristics (Gelibolu \& Tanrıkulu, 2014; Jolson \& Comer, 1997; Lagace \& Twible, 1990; McFarland \& Kidwell, 2006). Thus, androgynous people's high level of job satisfaction may be grounded on their adequate fulfillment of the requirements of the sales profession as a result of having androgynous characteristics. Furthermore, from the point of view of behavioral flexibility, the fact that androgynous individuals have an adaptation advantage, or in other words, they have the ability to display masculine or feminine behaviors as necessary and that they can give appropriate responses, act comfortably and thus adapt to unexpected situations (Jolson \& Comer, 1997), explains this high level of job satisfaction. Feeling adequate for the sales professions and having self-efficiency in career decision may also encourage the job satisfaction of androgynous individuals. Also, this finding was supported by the correlation between JSAT and both OC and JS observed in this study. Androgynous participants had positive feelings and emotions about their jobs, had less job stress and also had loyalty to their organization as related to this gratification.

Evaluation of the findings obtained in this study in consideration of the conditions in Turkey would be useful for both literature and practice. According to the Turkish Statistical Institute (TUIKK) (2015), the unemployment rate for males with bachelor degree was $23.4 \%$ while this rate for females was $34.4 \%$, so unemployment rate was higher for females (TUIKK, 2015). Women are mostly in the position of housewives in Turkey, where employment of women is much lower than employment of men. This can be considered as an effect of the lower level of intention to leave for female participants; however, it should be taken into account that men in Turkey have a major role of providing the income for the family. Therefore, men can show higher level of intention to leave than women for a job having higher income or women can show lower intention to 
leave because of the socioeconomic advantages of having a job. Moreover, one of the most distinct changes in the labor force profile is the increase in the participation of women in labor force in Turkey. In addition to the rapid increase in the participation of women in sales force, it may also be stated that the educational level of salespeople, especially in the health sector, is high. Thus, one of the reasons for women is that socializing, career, proving oneself, and economic opportunities provided by the sales profession increase job satisfaction and organizational commitment and decrease intention to leave for them. Another reason is the expectation of being freer, more flexible and adaptable in return for changing environmental conditions for modern Turkish women (Özkan \& Lajunen, 2005). Furthermore, mature and loyal role of women in Turkish culture may be seen as another reason of their high level of organizational commitment and low level of intention to leave.

Findings of the study allowed for the development of certain suggestions for administrative implications. Sex and gender become crucial agenda in management of sales force due to the increase in number of saleswomen and observed diversity of gender identity in society. Differences in sex and gender identity groups should be taken into account during the adjustment of management strategies. In this study, positive results about saleswomen and androgynous salesperson were achieved. As women have a higher level of job satisfaction and organizational commitment and lower level of intention to leave, they may be preferred in the sales profession. Besides, job satisfaction and organizational commitment of women may be enhanced by supporting them in overcoming the obstacles posed by being a woman by means of administrative implications (flexible working hours, home office working, training, etc.). Androgynous people have more of the characteristics that are emphasized and attempted to be provided by managers, namely high level of organizational commitment and job satisfaction and low level of intention to leave and job stress and, therefore, it is recommended to take androgenicity as an important criterion in the selection of salespeople. By promoting androgenicity in the motivation of current salespeople, it may be ensured that job outcomes of salespeople reach to the desired level. More satisfied job outcomes may be obtained from androgynous salespeople by supporting these characteristics of them through trainings. It may be also useful to encourage salespeople from other gender groups by means of trainings that will bring them androgynous traits, especially behavioral flexibility. As there are mostly masculine persons in the sales profession, these trainings should put emphasis on certain feminine characteristics, like loyalty, to steer them into androgenicity. It may also be useful to assign men and masculine persons with tasks by which they may put forward their characteristics like competition, displaying strength and leadership in order to increase their job satisfaction and organizational commitment.

Among gender identity groups, only masculine and androgynous groups were compared in this study. Therefore, the study gave no information concerning feminine and undifferentiated individuals. Besides, it is also seen in the sales literature reviews that participants of the previous studies are mostly masculine and androgynous (Comer \& Jolson, 1985; Lagace \& Twible, 1990; Tanrıkulu \& Efeoglu, 2015; Teer et al., 1992) and psychological genders of salespeople are characterized as androgynous (Gelibolu \& Tanrikulu, 2014; Lagace \& Twible, 1990). On the other hand, the differences among the mentioned groups showed that there was a difference among gender identity groups in general. Due to the sampling method used in the study, the sample only covered pharmaceutical salespeople and therefore the possibility to generalize findings of the study is restricted. Therefore, it is recommended for further studies to analyze salespeople in different sectors. Studies in this area may be grounded on quantitative and qualitative researches and longitudinal studies 
will be useful for following and understanding the changes in salespeople in accordance with the changes in gender identity in the course of time. In this study, only the psychological job outcomes were analyzed and it is recommended for future studies to examine the behavioral job outcomes. It is suggested that the gender role has an influence on work-related behaviors (Gianakos, 2000), while gender does not correspond to behavior, but individuals act in genderalized behavior patterns, which follow gender role identity (Woodhill \& Samuels, 2003). As studies on gender identity in the sales literature are inadequate, it would be useful to analyze behaviors of salespeople in terms of gender role for academic studies and practitioners to understand these behaviors.

In conclusion, this study pointed out that there already exist sex differences and also gender identity differences regarding the job outcomes in sales force. It revealed that there were differences of psychological job outcomes (excluding job stress) between saleswomen and salesmen and also masculine salesperson and androgynous salesperson. The fact that women had a high level of job satisfaction and organizational commitment and a low level of intention to leave may be accepted as a factor that strengthens the position of saleswomen in the sales force and shows that they adopt this profession. This study proved that, besides biological sex, gender identity as psychological gender may also be an important variable in the classification of salespeople and analysis of salespeople in terms of administrative variables, bringing a new and different approach to elucidate gender-based differences in job outcomes. Therefore, the main contribution of this study to the literature and practitioners is to give them an insight about the significance of gender identity to identify the difference of psychological job outcomes in sales force. Another contribution is being a pioneer study to investigate gender identity as a differential reason of salespeople in Turkey, where Western and Islamic cultures are mixed, gender identities have undergone a change, the number of saleswomen is increasing, and it is an attractive emerging market for global companies. This study also provides further understanding to implication that androgynous individuals have the most appropriate gender identity for sales profession, considering that they had a high level of job satisfaction and organizational commitment and a low level of job stress and intention to leave.

\section{Note}

1 Central limit theorem: The means of samples show normal distribution as the sample size increases (Nakip, 2003, p. 202). The sample size should be larger than 30 or 50 for this theorem to be used according to one of the common visions (Kurtuluş, 2004, p. 99).

\section{References}

Akgemci, T. (2001). Örgütlerde stres ve yönetimi. Journal of Economics and Administrative Sciences, 15(1-2), 301-309.

Altunışık R, Çoşkun, R., Yıldırım, E., \& Bayraktaroğlu, S. (2002). Sosyal bilimlerde araștırma yöntemleri: SPSS uygulamalı. Sakarya: Sakarya Kitabevi.

Arslan, S. (2014). The relationship between prospective teachers' love for children and "gender roles and some demographic qualities". Anthropologist, 18(3), 681-689.

Babakus, E., Cravens, D. W., Johnston, M., \& Moncrief, W. C. (1996). Examining the role of organizational variables in the salesperson job satisfaction model. Journal of Personal Selling \& Sales Management, 16(3), 33-46.

Beetles, A., \& Haris, L. (2005). Marketing gender and feminism: A synthesis and research agenda. The Marketing Review, 5(3), 205-231.

Bem, S. L., \& Lewis, S. A. (1975). Sex role adaptability: One consequence of psychological androgyny. Journal of Personality and Social Psychology, 31(4), 634.

Bem, S. L., Martyna, W., \& Watson, C. (1976). Sex typing and androgyny: Further explorations 
of the expressive domain. Journal of Personality and social Psychology, 34(5), 1016-1023.

Bickford, M. (2005). Stress in the workplace: $A$ general overview of the causes, the effects, and the solutions. Canadian Mental Health Association Newfoundland and Labrador Division, 1-3. Retrieved from http://www.cmhanl.ca/pdf/ Work\%20Place\%20Stress.pdf

Bilgiç, R. (2010). İşe ilişkin tutumlar, iş rolü algıları ve algılanan performans arasındaki ilişki. Amme İdaresi Dergisi, 43(4), 67-86.

Bolat, N., \& Odac1, H. (2016). High school final year students' career decision-making self-efficacy, attachment styles and gender role orientations. Current Psychology, 1-8. doi:10.1007/s12144016-9409-3.

Boles, J., Madupalli, R., Rutherford, B., \& Wood, J. A. (2007). The relationship of facets of salesperson job satisfaction with affective organizational commitment. Journal of Business \& Industrial Marketing, 22(5), 311-321.

Boles, J. S, Wood, J. A. \& Johnson, J. (2003). Interrelationships of role conflict role ambiguity and work-family conflict with different facets job satisfaction and the moderating effects of gender. Journal of Personel Selling \& Sales Management, 23(2), 99-113.

Brashear, T. G., Lepkowska-White, E., \& Chelariu, C. (2003). An empirical test of antecedents and consequences of salesperson job satisfaction among Polish retail salespeople. Journal of Business Research, 56(12), 971-978.

Buchanan, B. (1974). Building organizational commitment: The socialization of managers in work organizations. Administrative Science Quarterly, 19(4), 533-546.

Busch, P., \& Bush, R. F. (1978). Women contrasted to men in the industrial salesforce: Job satisfaciton values role clarity performance and propersity to leave. Journal of Business Research, 15(3), 438-448.

Cheng, C. (2005). Processes underlying genderrole flexibility: Do androgynous individuals know more or know how to cope? Journal of Personality, 73(3), 645-674.

Chai, J., Zhao, G., \& Babin, B. J. (2012). An empirical study on the impact of two types of goal orientation and salesperson perceived obsolescence on adaptive selling. Journal of Personel Selling \& Sales Management, 32(2), 261-273.

Choi, K. (2006). A structural relationship analysis of hotel employees' turnover intention. Asia Pacific Journal of Tourism Research, 11(4), 321-337.

Choi, S. E., \& Kim, S. D. (2016). A meta-analysis of the variables related to job satisfaction among Korean nurses. Contemporary Nurse, 52(4), 462476.

Clark, A. E. (1997). Job satisfaction and gender: Why are women so happy at work?. Labour economics, 4(4), 341-372.

Comer, L. B., \& Drollinger, T. (1996). Androgyny and relationship selling: Some possible linkages. Proceedings of the National Conference in Sales Management, Anaheim, CA, United States of America.

Comer, L. B., \& Drollinger, T. (1999). Active empathetic listening and selling success: A conceptual framework. Journal of Personal Selling \& Sales Management, 19(1), 15-29.

Comer, L. B., \& Jolson, M. A. (1985). Sexlabeling of selling jobs and their applicants. Journal of Personal Selling \& Sales Management, 5(1), 15-22.

Comer, L. B., \& Jolson, M. A. (1991). Perceptions of gender stereotypic behavior: An exploratory study of women in selling. Journal of Personal Selling \& Sales Management, 11(1), 43-59. 
Çabuk, S., \& Keleş, C. (2011). Satış yönetiminde cinsiyet ve iş tatmini. e-Journal of New World Sciences Academy, 6(1), 18-33.

Demirtaş-Madran, H. A. (2012). Cinsiyet, cinsiyet rolü yönelimi ve düşünme ihtiyaci. Türk Psikoloji Yazıları, 15(29), 1-10.

Demirtaş-Madran, H. A. (2016). Genişletilmiş kişisel yüklemeler ölçeğinin türkçe formunun geçerlilik ve güvenilirlik çalışması. Anatolian Journal of Psychiatry/Anadolu Psikiyatri Dergisi, 17(Suppl. 1), 60-68.

Dökmen, Z. Y. (1991). Bem cinsiyet rolü envanterinin geçerlik ve güvenirlik çalısması. Ankara DilveTarih-Cografya Fakültesi Dergisi, 35(1), 81-89.

Dökmen, Z. Y. (1999). Bem cinsiyet rolü envanteri kadınsılık ve erkeksilik ölçekleri Türkçe formunun psikometrik özellikleri. Kriz Dergisi, 7(1), 27-40.

Dökmen, Z. Y. (2003). Çalışma durumları farklı üç grup kadında ruh sağlığı, kontrol odağ ve cinsiyet rolü. Türk Psikoloji Dergisi, 18(51), 111-124.

Dubinsky, A. J., Jolson, M. A. J., Michaeles, R. E., Kotabe, M., \& Lim, C., (1993). Perceptions of motivational components: Salesmen and Saleswomen revisited. Journal of Personel Sellin \& Sales Management, 13(4), 25-37.

Eichinger, J. (2000). Job stress and satisfaction among special education teachers: Effects of gender and social role orientation. International Journal of Disability, Development and Education, 47(4), 397-412.

Eichinger, J., Heifetz, L. J., \& Ingraham, C. (1991). Situational shifts in sex role orientation: Correlates of work satisfaction and burnout among women in special education. Sex Roles, 25(7-8), 425-440.
Franke, G. R., \& Park, J. E. (2006). Salesperson adaptive selling behavior and customer orientation: A meta-analysis. Journal of Marketing Research, 43(4), 693-702.

Fu, W., \& Deshpande, S. P. (2014). The impact of caring climate, job satisfaction, and organizational commitment on job performance of employees in a China's insurance company. Journal of Business Ethics, 124(2), 339-349.

Gable M., \& Reed, B. J. (1987). The current status of woman in professional selling. Journal of Personel Selling \& Sales Managemen, 7(1), 33-40.

Gaur, S. P., \& Jain, S. S. (2013). Gender issues in work and stress - Stress and Work: Perspectives on Understanding and Managing Stress. Pestonjee: Sage Publications.

Gegez, A. E. (2010). Pazarlama araştırmaları. Beta Yayınları: İstanbul.

Gelibolu, L., \& Tanrıkulu, C. (2014). Satışçılarda cinsiyet kimliği: kavramsal bir inceleme. ÇÜ Sosyal Bilimler Enstitüsü Dergisi, 23(2), 243-252.

Gianakos, I. (2000). Gender roles and coping with work stress. SexRoles, 42(11-12), 1059-1079.

Goolsby, J. R., Lagace, R. R., \& Boorom, M. L. (1992). Psychological adaptiveness and sales performance. Journal of Personal Selling \& Sales Management, 12(2), 51-66.

Hair, J. F., Celsi, M. W., Money, A. H., Samouel, P., \& Page, M. J. (2011). Essentials of business research methods (2nd ed.). New York: M. E. Sharpe Inc.

House, R. J., \& Rizzo, J. R. (1972). Role conflict and ambiguity as critical variables in a model of organizational behavior. Organizational Behavior and Human Performance, 7(3), 467-505.

Hunt, S. D., Chonko, L. B., \& Wood, V. R. (1985). Organizational commitment and marketing. The Journal of Marketing, 49, 112-126. 
Jagacinski, C. M. (1987). Androgyny in a male-dominated field: The relationship of sextyped traits to performance and satisfaction in engineering. Sex Roles, 17(9-10), 529-547.

Jaramillo, F., Grisaffe, D. B., Chonko, L. B., \& Roberts, J. A. (2009). Examining the impact of servant leadership on salesperson's turnover intention. Journal of Personal Selling \& Sales Management, 29(4), 351-365.

Jaramillo, F., Mulki, J. P., \& Marshall, G. W. (2005). A meta-analysis of the relationship between organizational commitment and salesperson job performance: 25 years of research. Journal of Business Research, 58(6), 705-714.

Jaramillo, F., Mulki, J. P., \& Solomon, P. (2006). The role of ethical climate on salesperson's role stress, job attitudes, turnover intention, and job performance. Journal of Personal Selling \& Sales Management, 26(3), 271-282.

Johnson, J. S., \& Sohi, R. S. (2014). The curvilinear and conditional effects of product line breadth on salesperson performance, role stress, and job satisfaction. Journal of the Academy of Marketing Science, 42(1), 71-89.

Jolson, M. A., \& Comer, L. B. (1997). The use of instrumental and expressive personality traits as indicators of a salesperson's behavior. Journal of Personal Selling \& Sales Management, 17(1), 29-43.

Jones, K., Mendenhall, S., \& Myers, C. A. (2016). The effects of sex and gender role identity on perceived stress and coping among traditional and nontraditional students. Journal of American College Health, 64(3), 205-213.

Kara, A., Andaleeb, S. S., Turan, M., \& Cabuk, S. (2013). An examination of the effects of adaptive selling behavior and customer orientation on performance of pharmaceutical salespeople in an emerging market. Journal of Medical Marketing: Device, Diagnostic and Pharmaceutical Marketing, 13(2), 102-114.
Kennedy, E. J., \& Lawton, L. (1992). Men and women in industrial sales: Satisfaction and outcomes. Industrial Marketing Management, 21(1), 5-14.

Krausz, M., Kedem, P., Tal, Z., \& Amir, Y., (1992). Sex-role orientation and work adaptation of male nurses. Research in NursingeHealth. 15(5), 391-398.

Koca, C., Aşçi, F. H., \& Kirazcr, S. (2005). Gender role orientation of athletes and nonathletes in a patriarchal society: A study in Turkey. Sex Roles, 52(3-4), 217-225.

Kurtulus, K. (2004). Pazarlama arastirmalari (7th ed.). Istanbul: Literatür Yayincilik Dagitim Pazarlama San. Tic. Ltd. Sti.

Ladik, D. M., Marshall, G. W., Lassk, F. G., \& Moncrief, W. C. (2002). Reexamining gender issues in salesperson propensity to leave. Industrial Marketing Management, 31(7), 599-607.

Lagace, R. R., \& Twible, J. L. (1990). The androgyny level of salespeople: Gooses and ganders, or all geese? Journal of Social Behavior and Personality, 5(6), 641-650.

Lambert, E. G., Minor, K. I., Wells, J. B., \& Hogan, N. L. (2016). Social support's relationship to correctional staff job stress, job involvement, job satisfaction, and organizational commitment. The Social Science Journal, 53(1), 22-32.

Lipińska-Grobelny, A., \& Wasiak, K. (2010). Job satisfaction and gender identity of women managers and non-managers. International Journal of Occupational Medicine and Environmental Health, 23(2), 161-166.

Macintosh, G., \& Krush, M. (2014). Examining the link between salesperson networking behaviors, job satisfaction, and organizational commitment: Does gender matter? Journal of Business Research, 67(12), 2628-2635. 
Matud, M. P., Bethencourt, J. M., \& Ibáñez, I. (2014). Relevance of gender roles in life satisfaction in adult people. Personality and Individual Differences, 70, 206-211.

McFarland, R. G., \& Kidwell, B. (2006). An examination of instrumental and expressive traits on performance: Themediating role of learning prove and avoid goal orientations. Journal of Personal Selling and Sales Management, 26(2), 143-159.

McQuiston, D. H., \& Morris, K. A. (2009). Gender differences in communication: Implications for salespeople. Journal of Selling \& Major Account Management, 9(1), 54-64.

Moncrief, W. C., Babakus, E., Cravens, D. W., \& Johnston, M. W. (2000). Examining gender differences in field sales organizations. Journal of Business Research, 49(3), 245-257.

Mowday, R. T., Steers, R. M., \& Porter, L. W. (1979). The measurement of organizational commitment. Journal of Vocational Behavior, 14(2), 224-247.

Mulki, J. P., Jaramillo, F., Goad, E. A., \& Pesquera, M. R. (2015). Regulation of emotions, interpersonal conflict, and job performance for salespeople. Journal of Business Research, 68(3), 623-630.

Nakip, M. (2003). Pazarlama araştırmaları. Ankara: Seçkin Yayıncılık.

Naumann, E., Widmier, S. M., \& Jackson, D. W., Jr. (2000). Examining the relationship between work attitudes and propensity to leave among expatriate salespeople. Journal of Personal Selling \& Sales Management, 20(4), 227-241.

Nelson, D. L., \& Quick, J. C. (1985). Professional women: Are distress and disease inevitable? Academy of Management Review, 10(2), 206-218.

Newstrom, J. W., \& Davis, K. (1993). Organizational behavior human behavior at work (9th ed.). New York: McGraw Hill Inc.
Ozkan, T., \& Lajunen, T. (2005). Masculinity femininity and the Bem sex role inventory in Turkey. Sex Roles, 52(1-2), 103-110.

Paul, H., \& Garg, P. (2014). Organizational commitment of frontline sales professionals in India: Role of resilience. International Journal of Business Insights \& Transformation, 7(2), 12-18.

Ramkissoon, H., \& Nunkoo, R. (2012). More than just biological sex differences examining the structural relationship between gender identity and information search behavior. Journal of Hospitality \& Tourism Research, 36(2), 191-215.

Rivera-Torres, P., Araque-Padilla, R. A., \& Montero-Simó, M. J. (2013). Job stress across gender: The importance of emotional and intellectual demands and social support in women. International journal of environmental research and public health, 10(1), 375-389.

Robinson, L., Jr., Marshall, G. W., Moncrief, W. C., \& Lassk, F. G. (2002). Toward a shortened measure of adaptive selling. Journal of Personal Selling\& Sales Management, 22(2), 111-118.

Rutherford, B., Boles J., Hamwi, G. A., Madupalli, R., \& Rutherford, L. (2009). The role of the seven dimensions of job satisfaction in salespersons attitudes and behaviors. Journal of Business Research, 62(11), 1146-1151.

Rutherford, B. N., Marshall, G. W., \& Park, J. (2014). The moderating effects of gender and inside versus outside sales role in multifaceted job satisfaction. Journal of Business Research, 67(9), 1850-1856.

Sager, J. K., \& Wilson, P. H. (1995). Clarification of the meaning of job stress in the context of sales force research. Journal of Personal Selling \& Sales Management, 15(3), 51-63.

Schruijer, S. G. (2006). Do women want to break the glass ceiling? A study of their career orientations and gender identity in the Netherlands. Management Revue, 17(2), 143-154. 
Schul, P. L., \& Wren, B. M. (1992). The emerging role of women in industrial selling: A decade of change. The Journal of Marketing, 56(3), 38-54.

Seashore, S. E., Lawler, E. E., Mirvis, P., \& Cammann, C. (1982). Observing and measuring organizational change: A guide to field practice. New York: Wiley.

Selvarajan, T. T., Slattery, J., \& Stringer, D. Y. (2015). Relationship between gender and work related attitudes: A study of temporary agency employees. Journal of Business Research, 68(9), 1919-1927.

Sekaran, U. (2003). Research methods for business: A skills-building approach (4th ed.). New York: Wiley \& Sons.

Shen, C. Y. (2014). The Relative study of gender roles, and job stress and adversity quotient. Journal of Global Business Management, 1O(1), 19-32.

Shukla, A., \& Srivastava, R. (2016). Influence of ethical ideology and socio-demographic characteristics on turnover intention: A study of retail industry in India. Cogent Business \& Management, 3(1), 1-21.

Siguaw, J. A., \& Honeycutt, E. D., Jr. (1995). An examination of gender differences in selling behaviors and job attitudes. Industrial Marketing Management, 24(1), 45-52.

Sims, R. L., \& Sun, P. (2012). Witnessing workplace bullying and the Chinese manufacturing employee. Journal of Managerial Psychology, 27(1), 9-26.

Spiro, R. L. \& Weitz, B. A. (1990). Adaptive selling: Conceptualization measurement and nomological validity. Journal of Marketing Research, 27(1), 61-69.

Swan, J. E., Futrell, C. M., \& Todd, J. T. (1978, January). Same job different views: Women and men in industrial sales. The Journal of Marketing, 42(1), 92-98.

Swimberghe, K., Jones, R. P., \& Darrat, M. (2014). Deviant behavior in retail, when sales associates "Go Bad"! Examining the relationship between the work-family interface, job stress, and salesperson deviance. Journal of Retailing and Consumer Services, 21(4), 424-431.

Tanrikulu, C. (2014). Examination of sex and gender identity differences of consumers in green behaviour. Journal of Environmental Protection and Ecology, 15(3), 1315-1327.

Tanrikulu, C., \& Efeoglu, I. E. (2015). Examination of the differences in selling behavior on the basis of sex and gender identity. Journal of Management Policies and Practices, 3(1), 59-68.

Teer, H. B., Tobacyk, J. J., \& Dawson, L. E., Jr. (1992). Sex-role self-concept and direct sales success in minority saleswomen. Journal of Marketing Channels, 2(2), 71-78.

Tükiye Istatistik Kurumu (2015). Dünya Nüfus Günü-2014. Retrieved from http://www.tuik.gov. tr/PreHaberBultenleri.do?id=15975

Turunç, Ö., \& Erkuş, A. (2010). İş-aile yaşam çatışmasının iş tatmini ve örgütsel bağlılık üzerine etkileri: İş stresinin aracılık rolü. SÜ İIBF Sosyal Ve Ekonomik Araştırmalar Dergisi, 19, 415-440.

Twenge, J. M. (1997). Changes in masculine and feminine traits over time: A meta-analysis. Sex Roles, 36(5-6), 305-325.

Tyagi, P. K., \& Wotruba, T. R. (1998). Do gender and age really matter indirectselling? An exploratory investigation. The Journal of Marketing Management, 8(2), 22-33.

Ushasree, S., Seshu Reddy, B. V., \& Vinolya, P. (1995). Gender, gender-role and age effects on teachers' job stress and job satisfaction. Psychological Studies, 40(2), 72-76. 
Weisberg, J., \& Kirschenbaum, A. (1993). Gender and turnover: A re-examination of the impact of sex on intent and actual job changes. Human Relations, 46(8), 987-1006.

Weiss, D. J., Dawis, R. V., \& England, G. W. (1967). Manual for the Minnesota satisfaction questionnaire (Minnesota studies in vocational Rehabilitation, Vol. 22). Minneapolis: University of Minnesota, Industrial Relations Center.

Weitz, B. A., \& Bradford, K. D. (1999). Personal selling and sales management: A relationship marketing perspective. Journal of the Academy of Marketing Science, 27(2), 241-254.

Winterich, K. P., Mittal, V., \& Ross, W. T. (2009). Donation behavior toward in-groups and outgroups: The role of gender and moral identity. Journal of Consumer Research, 36(2), 199-214.

Wood, W., \& Eagly, A. H. (2012). Biosocial construction of sex differences and similarities in behavior. In J. M. Olson \& M. P. Zanna (Eds.), Advances in Experimental Social Psychology (Vol. 46, pp. 55-123). Burlington: Academic Press.

Wood, W., \& Eagly, A. H. (2015). Two traditions of research on gender identity. Sex Roles, 73(1112), 461-473.
Woodhill, B. M., \& Samuels, C. A. (2003). Positive and negative androgyny and their relationship with psychological health and wellbeing. Sex Roles, 48(11-12), 555-565.

Wren, B. M., Berkowitz, B., \& Grant, E. S., (2014). Attitudinal, personal, and job-related predictors of salesperson turnover. Marketing Intelligence \& Planning, 32(1), 107-123.

Wu, Y. C., \& Shih, K. Y. (2010). The effects of gender role on perceived job stress. The Journal of Human Resource and Adult Learning, 6(2), 74-79.

Yağc1, M. İ., \& İlarslan, N. (2010). The effect of advertisements and gender identity role on consumer buying behavior. Doğuş University Journal, 11(1), 138-155.

Yapraklı, Ş., \& Yılmaz, M. K. (2007). Çalışanların iş stresi algılarının iş tatminleri üzerindeki etkisi: Erzurum'da ilaç mümessilleri üzerinde bir saha araştırması. Atatürk Üniversitesi İktisadi İdari Bilimler Dergisi, 21(1), 154-183.

Yoon, H. J., \& Kim, Y. (2014). The moderating role of gender identity in responses to comedic violence advertising. Journal of Advertising, 43(4), 382-396. 


\section{Supporting agencies:}

This study was supported by Adana Science and Technology University, Unit of Scientific Research Projects with the project number IF.UT.2014-3.

\section{About the authors:}

1. Ceyda Tanrikulu, Ph.D. in Business Administration (Marketing), Adana Science and Technology University, Turkey. Email: ctanrikulu@adanabtu.edu.tr

ORCIID

(iD) $0000-0001-9025-583 \mathrm{X}$

\section{Contribution of each author:}

Contribution

\section{Ceyda Tanrikulu}

1. Definition of research problem

2. Development of hypotheses or research questions (empirical studies)

3. Development of theoretical propositions (theoretical Work)

4. Theoretical foundation/ Literature review

5. Definition of methodological procedures

6. Data collection

7. Statistical analysis

8. Analysis and interpretation of data

9. Critical revision of the manuscript

10. Manuscript Writing 